\title{
MĀORI DIALECT ISSUES AND MĀORI LANGUAGE IDEOLOGIES IN THE REVITALISATION ERA
}

\author{
Peter J. Keegan*
}

\begin{abstract}
In recent times, during the Māori language revitalisation era, there has been a renewed interest in learning and promoting Māori dialects. Iwi identification is often signalled by younger speakers of Māori through pronunciation, idiom, vocabulary and written forms that are thought to be associated with a particular iwi or region. To date, there has not been promotion of a standard form of Māori; standardisation efforts have instead largely focused on lexical/technical development and promoting orthographic consistencies for writing Māori. Māori language is changing because of the need to create a new language for the modern world, along with dramatic changes, especially in the pronunciation of Māori, mostly due to influences from New Zealand English. This paper discusses the literature on linguistic dialect variation, the historical context, and contemporary issues and tensions related to dialect usage and language change which have arisen in the language revitalisation era. It suggests that renewed interest in dialects can be framed in relation to overt expressions of what are sometimes termed "language ideologies" or beliefs about language. It is argued that further research is required on Māori language ideologies in general, attitudes towards dialects and motivations for using them, and Māori language use amongst younger speakers of Māori.
\end{abstract}

\section{Keywords}

te reo Māori, Māori dialects, Māori language change, Māori language ideologies

* Waikato-Maniapoto, Ngāti Porou. Senior Lecturer, Te Puna Wānanga, School of Māori and Indigenous Education, Faculty of Education and Social Work, University of Auckland, Auckland, New Zealand.

Email: p.keegan@auckland.ac.nz

DOI: 10.20507/MAlJournal.2017.6.2.3 


\section{Introduction}

Major gains have been made in the revitalisation of te reo Māori over the last three decades. The sociolinguistic survey undertaken between 1973 and 1979 by Richard and Nena Benton of the New Zealand Council for Educational Research clearly showed that, with the exception of a few isolated rural communities, the vast majority of Māori children were not being brought up as speakers of Māori (Benton, 1991). In the 1980s, kōhanga reo and kura kaupapa Māori emerged as two forms of Māori medium education that sought to ensure the survival of the language, and are now well known internationally. In addition to efforts focusing on the compulsory school sector, universities and other tertiary institutes, iwi and community organisations such as Te Ataarangi have taught Māori language to many thousands of learners and undertaken a great deal of Māori language promotion.

The teaching of Māori language to adults benefited immensely from work undertaken by the late Bruce Biggs to describe Māori in structural frameworks. Such an approach became popular in linguistics after World War II (Biggs, 1961). Scholars who have built on Biggs's pioneering work include Hohepa (1967) and Reedy (1979), and, in more recent decades, Bauer (1981, 1993, 1997) and Harlow (2001, 2007, 2015). Biggs also produced a grammar for teaching Māori (Biggs, 1969) and dictionaries (Biggs, 1966, 1981). Most of the authors describing the structure of Māori include comments about Māori dialects and regional variation. Papers focusing specifically on Māori dialects, such as those of Reedy (1979) and Biggs (1989), clearly state the need for further research on Māori dialects because sources of data are largely restricted to wordlists and observations, and no systematic large scale studies have been undertaken.

Teaching resources for the nascent Māori medium sector have been largely created by native speakers of Māori (e.g., Katarina
Mataira, who wrote novels and a wide range of children's picture books in Māori) and are written in the dialect of their iwi. Set up in 1987, Te Taura Whiri i te Reo Māori-Māori Language Commission (hereafter Te Taura Whiri) has been responsible for overseeing the production of Māori curriculum statements and ensuring that government-produced Māori language materials are of an acceptable standard. It is interesting to note that, other than the promotion of orthography consistency for use in official government publications, including those produced for the Māori medium education sector and the broadcasting industry, there is not yet an acknowledgement of the need for a standardised form of Māori.

This paper discusses the recent renewed interest in iwi dialects, which have become popular amongst many second language learners of Māori involved in Māori language revitalisation efforts. The new enthusiasm for dialects needs to be considered in the larger historical context of Māori language change, including contemporary trends. It is argued that the interest in dialects can be regarded as an example of a language ideology which is termed a "dialect ideology". Examples of dialect ideologies are provided along with possible rationales for their use. The attitudes that speakers may have towards language and their own iwi are also explored, and further areas of research are outlined.

\section{The nature of Māori dialects}

Māori dialects do not, in fact, show a great deal of variation (Harlow, 2007). Differences are generally well known by fluent speakers of Māori and this does not hinder communication. Linguists tend to recognise an East-West split for New Zealand. The North Island is split somewhat in alignment with the central mountain ranges with Te Arawa, Mātaatua, East Coast and Ngāti Kahungunu tribal regions in the eastern area, and elsewhere in the North 
Island and upper South Island in the western area. Although sharing eastern features, the Ngāi Tahu dialect, once spoken in most areas of the South Island, has unique features as a result of a sporadic assimilation, for example, "poueru" for the widely used "pouaru" and "pounemu” for "pounamu” (Harlow, 2007, p. 48). There is also minor variation within these regions and even within tribal groups, which are in some cases spread over large geographical areas.

Māori dialects show slight variation in terms of phonological features, grammar, vocabulary and idiom and in borrowings from other languages, especially English. Phonological differences are well known amongst Māori speakers. Perhaps the most familiar is the variation in the production of the phoneme /f/ (written as <wh>). In modern Māori, most dialects pronounce $<w h>$ in a way very similar to an English /f/. In Northland, speakers often use bilabial articulations for $<w h>$ and $/ h /$ for the $<w h>$ in the causative prefix "whaka-". Clear evidence exists that in previous generations a number of different pronunciations of $<$ wh $>$ were produced by individual speakers (Maclagan \& King, 2002). In the Taranaki/ Whanganui regions, $/ \mathrm{h} / \mathrm{w}$ was often replaced by a glottal stop, and $<w h>$ is produced as a glottalised /? w/. Tūhoe speakers often pronounce the velar nasal $/ \mathrm{g} /$ as an alveolar nasal $/ \mathrm{n} /$-in other words these two sounds have merged. Grammatical differences include preferences for certain constructions. For example, eastern speakers are reported to use "kei te ..." as the continuous/progress aspect marker, whereas " $\mathrm{e}$ ... ana" is preferred in western areas. Sometimes unique regional features are attested; for example, Northland speakers often use "kourua" for the second person dual pronoun while "kōrua" is used elsewhere. An example of lexical variation is the word for potato, which in most areas is "rīwai". Ngāti Porou speakers tend to use "parareka" and Taranaki speakers are reported to use "taewa" (this word, probably a borrowing, is also used in some parts of Ngāti
Kahungunu). Māori borrowings of English terms also vary amongst dialects: most speakers use "ngeru" for cat while some speakers from Northland use "poti" and in other areas "tori" is used. There are examples of regions using a borrowing where an equivalent Māori word is available; for example, many Northland speakers use "nō" for "kāore".

Benton (1991) clearly demonstrated that by the 1970s Māori had ceased to be an everyday community language. With the exception of rural Māori communities in parts of Northland and central and eastern regions of the North Island, the language had become largely restricted to traditional ceremonies and religious events. The result was the loss of knowledge of Māori dialects and regional variation, along with a break in intergenerational transmission of Māori. A further factor impacting on the use of Māori was the large scale urbanisation of the Māori population prior to the revitalisation efforts of the 1980s. This meant there were fewer opportunities to use the language and more contact with speakers of other dialects, which is likely to have also caused some dialect levelling amongst urban dwellers.

It is not unreasonable, therefore, to expect that some of the dialect features, especially the lexical variations discussed above, are no longer used by younger speakers of Māori who are products of Māori medium education. They have grown up outside of their traditional dialect areas and have mostly been taught by second language speakers of Māori. They are also unlikely to have encountered a lot of variation in the written Māori readily available, owing to the fact that official publicationsespecially those sponsored by the Ministry of Education-are mostly written by speakers from the eastern regions.

Finally, it is worth pointing out that the term dialect can be a potential source of confusion. According to the Waitangi Tribunal (2011),

The terms "dialect", "mita", "tribal reo", and "reo a iwi" have many interpretations. Some 
commentators describe dozens of 'dialects' within the reo of one particular iwi, while others identify variations across distinct geographical divides. Ngāti Porou Rūnanga chair Dr Apirana Mahuika told us that he "bristled" at the use of the phrase "tribal dialects", and stated that "te reo ake o Ngāti Porou is not a tribal dialect. It is my language and therefore all that I am.”

Our own view is that dialectal differences are important and, at times, pronounced in terms of idiom and accent. But the differences are not sufficient to impede verbal understanding between native speakers from different tribal areas. Indeed, despite effectively describing te reo ake o Ngāti Porou as a separate language, Dr Mahuika also explained that "there are areas of commonality in all the different reo of the different iwi. So that if you sit down and listen to a native speaker speaking the reo irrespective of where that person may come from you understand it." (vol. 2, p. 388)

\section{Māori language change}

Recent Māori language change has dramatically impacted Māori language, including Māori dialects. The reintroduction of Māori as a language of instruction into the compulsory school sector in the late 1970s has resulted in the language undergoing considerable lexical expansion in order to be able to cope with everyday classroom activities, and to allow speakers to talk about the modern world and its associated new technologies. Since its inception in 1987, Te Taura Whiri has been responsible for overseeing lexical expansion in Māori. It has produced two dictionaries of neologisms ( $\mathrm{Te}$ Taura Whiri, 1992, 1996), published new terms in its newsletter He Muka, completed a Māori language dictionary, He Pātaka Кирu (2008) (in Māori only), and overseen the development of Māori medium curriculum statements for the Ministry of Education and specialist dictionaries (Christensen, 2004, 2010; Ministry of Education, 1995).

Methods employed by Te Taura Whiri for creating new words are well discussed in the literature (Harlow, 2007; Keegan, 2005). There have been ongoing debates, however, regarding the practice of purging well-established borrowings from English, such as the days of the week and months of the year, and replacing them with terms based on traditional Māori word forms. This is mentioned in the recent Wai 262 report (Waitangi Tribunal, 2011). Piripi Walker, a well-known Māori broadcaster and Māori language advocate, questions the purging of "transliterations" without wide consultation amongst iwi as borrowings are commonly known amongst Māori speakers. Te Puni Kōkiri official and former Te Taura Whiri staff member Stephen (Tipene) Chrisp has claimed that alternative forms to borrowings were only suggestions and created in response to requests by Māori speakers. Clearly, there are some purists who believe that the language would somehow be better off if borrowings were purged. Others, especially older speakers, sometimes see this as an unwanted intrusion on their own language forms. In the Wai 262 report the late Dr Apirana Mahuika, a widely regarded Ngāti Porou leader, portrayed himself

as fighting a battle against the work of Te Taura Whiri, metaphorically suggesting he was constantly having to dig the Te Taura Whiri weeds out of his garden in order to plant the seed of te reo ake o Ngāti Porou. $\mathrm{He}$, like other claimants, described much of the "new language" as "unintelligible". All he wanted was to hear a language on the Māori news that any native speakers could understand, he explained, rather than one few could. (Waitangi Tribunal, 2011, vol. 2, p. 390)

Despite the objections of older native speakers, the proposed new terms for the days of the week and months of the year are now commonly 
used in Māori medium education settings and amongst second language learners of Māori. Speakers who have greater interaction with older native speakers simply revert to borrowings when it is clear that the audience may not be familiar with, or think highly of, new terminology.

Another area where Māori language has changed is in pronunciation. Older speakers of Māori often state that the Māori being produced by younger speakers sounds different or that the mita has changed. Whilst it is not always clear what aspects of pronunciation change are being commented upon, research clearly demonstrates that te reo Māori has changed. The MAONZE (Māori and New Zealand English) project has used recordings from three sets of speakers to track changes in the pronunciation of Māori and evaluate the influence from English (Harlow, Keegan, King, Maclagan, \& Watson, 2009; Watson, Maclagan, King, Harlow, \& Keegan, 2016). The first group of speakers were born in the late 19th century and were recorded mostly from 1946 to 1948. Most of these recordings are part of the Radio New Zealand Mobile Unit archive. The second group of speakers are kaumātua/kuia born between 1920 and 1940, and the third group are young speakers born between 1970 and 1990. The project results clearly show changes in both vowel quality and vowel duration (especially decreasing length of long vowels other than $/ \bar{a} /)$, and some evidence of diphthong mergers, especially amongst the younger speakers (Harlow et al., 2009; Watson et al., 2016). The MAONZE project has reported gender differences, with female speakers from all three age groups being ahead of the male speakers in terms of raising the short vowels /e/ and /o/ and in glide weakening in the diphthongs (King, Watson, Maclagan, Harlow, $\&$ Keegan, 2010). The young women are also in advance of the young men in $/ \mathrm{u} /$ fronting. Project team members are currently exploring how the rhythm of Māori has changed.
In addition to changes in pronunciation, the MAONZE project has provided clear evidence of other shifts in Māori language use (Harlow et al., 2009; Watson et al, 2016). The tense/aspect marker "ka" has historically two allomorphs: $/ \mathrm{ka}$ :/ is used when the rest of the verb phrase consists of only two morae (a mora consists of a syllable of the shape consonant-vowel; "morae" is the plural of "mora"; see Bauer, 1993); and /ka/, for longer phrases. Recordings of the first group of speakers, who were born in the late 1800 s, show that this distribution was observed with a high degree of consistency in the mid-20th century. However, the more recent recordings show variable behaviour, with modern younger speakers tending to show loss of both the allomorphy and consistent use of the short form. It is suggested that the shift is a result of both a proportional increase in the use of longer phrases over the same period and the decreasing use of Māori generally, so that there have been fewer opportunities to acquire the rule.

Many fluent speakers of Māori and linguists firmly suspect that the grammar of younger speakers of Māori is different to that of previous generations. Clear examples of these syntactical changes over time identified by Kelly (2015) include changes in relative clause structure, the use of the preposition "mō" and changing usage of two common verbs, "taea" and "āhei". She describes other changes in syntax based on her own observations as a Māori language teacher in a university (Kelly, 2014). Therefore, it is highly likely that younger speakers' grammar is much more simplified and consists of influences from English in terms of word order or syntax, and that many Māori lexical items are being used as simple equivalents of their English translation with a loss of their traditional Māori senses and/or syntax. Clearly this an area for further research; longitudinal studies of acquisition of Māori into adulthood and beyond would be extremely beneficial. 


\section{Is there a "standard Māori language"?}

Bruce Biggs (1952, p. 182) claimed that "standard Māori" was based on the Māori in the Ngāpuhi and Waikato districts, which are closely related. It was in these areas where missionaries had learnt Māori, which enabled them to produce Te Paipera. Biggs asserted that many regarded this as the standard and that the speech of such areas as Te Urewera, the East Coast, and the Bay of Plenty was considered to be dialect. It was also noted that the speech of any one area is not inherently superior to that of any other, which suggests that no one single dialect had become prestigious or was considered to be a better form of Māori than any other. Bishop Manu Bennett, in his submission to the Waitangi Tribunal (1986) for the Te Reo Māori claim, strongly argued that biblical Māori was standard for the whole of New Zealand and was understood everywhere.

It is almost certain that Te Paipera is less well known amongst younger speakers of Māori than in previous generations. Along with the general decline in Christianity in New Zealand, there has been a move by some Māori involved in Māori revitalisation efforts to seek out more traditional forms of spirituality and karakia. In some cases this has resulted in a purging of direct references to Christianity, which has become perceived as another form of colonisation. Furthermore, Te Paipera was last revised in the 1950s and contains vocabulary and archaic forms of Māori that would be difficult for younger Māori speakers to understand without a good knowledge of the Bible in English. It is encouraging to note that the Bible Society of New Zealand published a version of the New Testament in Māori in 2012 using current spelling conventions (including macrons) and is reported to be working on a new modern Māori translation of the New Testament.

It may be argued that Māori from the western regions of New Zealand is no longer the de facto for standard Māori in the 21st century. For second language learners in the 1970s and 1980s, Hoani Waititi’s (1970, 1972, 1978) eastern-based Te Rangatahi series was one of the few Māori language textbooks available. Since that time, many writers of Māori for learners, such as Ruka Paora, Katarina Mataira and Tīmoti Kāretu, have originated from eastern regions. John Moorfield's well known Te Whanake series of textbooks, multimedia and e-resources is largely based on Māori from the eastern region (see www.tewhanake.maori.nz). Whilst exact figures are unavailable, in recent decades many native speakers who were teachers of Māori and Māori educators working for the Department of Education (known as the Ministry of Education since 1989) hail from the eastern region. The first Māori language commissioner, Tīmoti Kāretu, and many Te Taura Whiri staff members are from eastern regions. Moreover, there seems to have always been a strong representation of speakers from eastern regions in the broadcasting sector, especially in Māori Television.

Certain forms of eastern features of Māori such as the plural personal pronouns "rātou", "mātou", and "tātou" are pronounced as "rātau", "mātau", and "tātau" by almost all younger speakers of Māori, although they are probably mostly still written with the former spellings rather than the latter, with the exception of some older native speakers who have grown up in eastern regions. It would not be surprising if the predominant progressive marker for younger speakers is the eastern "kei te ...", as opposed to the western "e ... ana". The spread of more widely spoken dialect features and the loss of less common features from smaller or less influential dialect features are part of a natural process of dialect levelling rather than one dialect gaining prominence over others.

\section{Towards a written standard for Māori}

Te Taura Whiri's (2012) Guidelines for Māori Language Orthography appears to have been 
adopted by many involved in the production of Māori language materials. It has also overseen or ensured that the Māori language of official documentation is of a very high standard. It has always worked closely with the Ministry of Education, especially overseeing important Māori language documents such as Te Marautanga o Aotearoa-The Curriculum of New Zealand (Ministry of Education, 2012), and the seven associated Māori language curriculum statements. Te Taura Whiri has also worked closely with the Māori broadcasting sector. It appears that the language used in the above documents is more based on an eastern variety than other regions, reflecting the origins of the Te Taura Whiri staff involved in this work. The language of the documents can be difficult for some teachers who are not proficient speakers of Māori to understand. One group, based in Te Taitokerau, produced their own rewritten version of an earlier version of the current curriculum (Everitt, 1996), which was claimed to be much more transparent to local speakers of Māori. It is beyond the scope of this paper to discuss issues of standardisation of both written and spoken Māori in the revitalisation era.

\section{Renewed interest in Māori dialects}

In my view, in recent times many younger speakers of Māori, especially second language learners, have become interested in learning their own iwi dialect. There is little data to support this claim, which is primarily based the author's observations as a fluent speaker of Māori and his involvement with his whānau and the Māori medium education community over the last three decades. Interest in learning and revitalising dialects is also reflected in comments recorded in recent publications such as Te Matatana o te Reo-A National Research Agenda for Regeneration and Revitalisation of Te Reo Māori (Pihama \& Matamua, 2017) and "He hua rānei tō te reo Māori mō ngā rā kei te heke mai?" (MacLeod, 2014), in addition to comments in the previously mentioned Wai 262 report (Waitangi Tribunal, 2011).

I am not using "dialect” here in a strictly linguistic sense of significant variation in language. Instead, it is being used as a synonym for iwi/regional variation or iwi/regional markers. Second language learners are often interested in learning about, and using, phonological forms and lexical items that may have been or are still being used in their traditional iwi region. Thus, language usage is being deployed as an overt identity iwi marker, very much in a similar fashion to tāmoko, which have become popular amongst many Māori involved in Māori language and cultural renaissance activities such as kapahaka.

The recent interest in dialects quite possibly originated in the mid-1970s. One regional grouping of three iwi (Ngāti Raukawa, Ngāti Toa, Te Ati Awa) based in Ōtaki instigated a farsighted strategic plan in 1975 titled "Whakatupuranga Rua Mano-Generation 2000" (Winiata, 2010). Māori language was an important component of that plan. A survey found that there were very few speakers of Māori in the region under the age of 30, and that urgent action was needed. This led to the establishment of Te Wānanga o Raukawa in 1981. The teaching of Māori language has always been a key component of Te Wānanga o Raukawa, with a strong emphasis on the local dialect or the forms of Māori spoken in that region.

Interest in learning an iwi variety of Māori can certainly be found throughout the country. Other iwi groups actively involved in promoting their own dialects include Taranaki, whose efforts began in the 1980s and are detailed at www.taranakireo.co.nz. One important initiative is the creation of a Taranaki dictionary, Te Puranga Takupu o Taranaki, which can be accessed through the website. Ngāi Tahu (Kai Tahu), especially since receiving their treaty settlement in 1998, have been actively promoting their own dialect (see www.kmk.maori.nz). 
Another example of a dialectal/regional dictionary is Te Papaku o te Taitokerau, available at www.temarareo.org/PAPAKUPU/dictionary-index.htm. A project has also recently begun to compile a Māori dictionary of the Ngāpuhi dialect for Te Wharetapu o Ngāpuhi in Whangārei ("Ngāpuhi Dialect", 2010). The project team is based at Te Wānanga o Te Tai Tokerau (NorthTec).

One of the larger iwi, the East Coast Ngāti Porou, is fortunate that the Ngata (2003) dictionary is based on their dialect (and is reportedly under revision). Native speakers of Ngāti Porou relate that there is variation in the Ngāti Porou region, which covers a large area of the East Coast of the North Island. Te Rūnanga o Ngāti Porou report that (probably based on 2006 Census data) only a sixth $(12,402)$ of the total Ngāti Porou population $(71,895)$ live within the Gisborne rohe, and that these are likely to speak te reo ake o Ngāti Porou (Te Taura Here o Ngāti Porou ki Tāmaki, 2009). Ngāti Porou has taura here based in most of the major urban centres of New Zealand. One of these major urban groups, Ngāti Porou ki Tāmaki, has developed a strategic plan and is active in promoting te reo Nāti amongst its members (for more recent statistics on the number of Māori speakers by iwi see Keegan, 2017).

Not all fluent speakers of Māori are convinced that it is possible for those living outside of the region to learn an iwi/regional variety. Tuteira Pōhatu, a Ngāti Porou pakeke and native speaker of Māori who grew up on the East Coast and has lived for many years in Auckland, suggested to taura here members that it was not possible for them to learn to speak Māori as he had (personal communication, September 2010). He believed their home environments had changed too much from the largely Māori-speaking community he had been raised in. After many years of living in the city and interaction with speakers from other regions, he also believed that his own language had changed. His comments suggest that in urban environments dialect or regional levelling is inevitable because younger speakers are for the most part exposed to speakers from different regions and to teachers who are mostly second language learners themselves.

Another area illustrating the resurgent interest in dialects can be found in written Māori, especially with respect to proper nouns. A Taranaki kura kaupapa Māori describes itself as Te Pi'ipi'inga Kakano Mai Rangiatea, using either an apostrophe or an inverted apostrophe to represent the glottal stop, which as mentioned earlier is a feature of the Taranaki/ Whanganui region. Sometimes Ngāi Tahu/Kai Tahu names are spelt with a " $k$ " but would be written as the digraph "ng" elsewhere. An example of this is the local term for the Southern Alps, which is written as Kā Tiritiri o te Moana. It seems that Ngāi Tahu is the most active iwi in terms of promoting their own orthography. Some Northern speakers now write the causative prefix "whaka-" as "haka-". Some Tūhoe speakers do not include the "g" when writing the diagraph "ng"; for example, "hunga" may be written as "huna".

Approximately 20 iwi radio stations are being funded by the government to deliver eight hours of Māori language content every day. Many iwi also have websites with Māori language content, which provide another medium for the promotion of Māori dialects. These initiatives and the other kinds of activity and energy described above concerning dialects and regional/iwi variations sit inside and interconnect with broader issues and concerns about Māori language change and survival into the future.

\section{Maori language attitudes, Māori language ideologies}

Important insights into the future survival of Māori language derive from research on attitudes towards Māori language. Recent important work on attitudes has focused more on non-Māori (Albury, 2016; de Bres, 2011). 
The most well-known are probably surveys undertaken by Te Puni Kōkiri-Ministry of Māori Development, the last of which was conducted in 2009. This research, whilst important and useful, does not involve large samples and is not statistically representative of New Zealand, and therefore needs careful interpretation. Harlow (2005) correctly points out that overt practices and opinions of Māori speakers which seem to reflect positive attitudes towards Māori language may in fact derive from covert negative attitudes that are inimical to Māori language maintenance and revival. In other words, it is extremely difficult to determine covert attitudes through practices and opinions. In measurement terminology, there are likely major validity issues with survey instruments and other methods of collecting data on attitudes.

Language ideologies (also referred to as linguistic ideologies) play an important role in language revitalisation programmes. These are ideologies or beliefs, ideas, conceptualisations, attitudes and feelings that speakers have about languages; that is, their structure and uses. It is important to note that ideologies may not necessarily be correct or have any sound basis in research. Schieffelin, Woolard and Kroskrity's (1998) edited collection is a seminal work on language ideologies, and Makihara and Schieffelin (2007) detail examples of language ideologies in Pacific societies. There is now a wide range of literature on language ideologies. A recent chapter by King (2014), focusing on Māori language revitalisation, discusses "revitalisation ideologies" and how these differ at institutional and vernacular levels, noting that vernacular ideologies will vary amongst different groups in the population and over time, especially between generations. By extension, a central claim of this paper is that there has been a recent renewed interest in iwi/regional dialects, especially by younger speakers. In other words, "dialect ideologies" is clearly a specific type or subset of a revitalisation ideology.
One example of a recent dialect ideology, or possibly a wider language ideology, is that an individual should write Māori (even in formal publications) exactly how they speak it, rather than using Te Taura Whiri's established standard form of spelling and orthography. This is evident in spellings (i.e., proper nouns), as previously mentioned, but also in multiple author publications. For example, The Value of the Māori Language: Te Hua o te reo Māori (Higgins, Rewi, \& Olsen-Reeder, 2014) consists of articles in English and Māori, with at least one of the latter chapters written using dialect spelling/orthography. Māori dialect orthographies are well attested in Māori language posts on social media platforms such as Facebook, although the use of Māori language in social media is another idea that requires further research. A somewhat different example of a dialect ideology is evidence in the comments quoted above by the late Apirana Mahuika in Wai 262 on te reo ake o Ngāti Porou.

\section{Discussion}

Māori language revitalisation efforts are fortunate to have coincided with some large iwi Treaty of Waitangi claims and settlements, along with renewed interest in iwi-based education initiatives such as wānanga. This has resulted in some iwi becoming better organised and in some cases multimillion dollar organisations (e.g., Waikato-Tainui, Ngāi Tahu). Language is very much part of iwi identity. Many younger Māori are keen to signal iwi allegiance and therefore are eager to use forms of language thought to be associated with their own iwi. Attempts by younger speakers to imitate the dialects of older native speakers, especially when those dialects themselves are not yet well studied, may sound strange to older native speakers. The lexical items and idioms may be correct; however, the pronunciation of the older native speakers is difficult to achieve. The MAONZE project has clearly demonstrated that the Māori spoken by 
younger speakers is significantly different to that of previous generations in terms of vowel quality and quantity. Work is currently under way on changes in the rhythm of Mãori. It is well known that older speakers comment that the mita (in this sense referring to rhythm or speech) of younger speakers has changed. This is not salient to younger speakers who are mostly unaware or unlikely to readily accept that their Māori is heavily influenced by New Zealand English, and very different to that used by their grandparents. In absence of good written records or sustained older native speaker contact, it may be argued that younger speakers of Māori are merely inventing new dialect forms or registers.

It is not easy to determine the covert attitudes that underlie dialect ideologies. Following Harlow's (2005) observations, it certainly is possible that covert attitudes towards dialects are not always positive. In other words, dialect ideologies may signal dislocations or even resentments of younger Māori speakers who, through urbanisation, have had little exposure and involvement in their own iwi. It may possibly reflect the inadequacy of individuals whose iwi dialects have long fallen out of use. The attitudes that underlie dialect ideologies are areas for further research.

A recent New Zealand development is the establishment of an independent group, Te Mātāwai, formed under the terms of Te Ture mō te Reo Māori 2016-Māori Language Act 2016. This is a 13-member organisation (including seven iwi representatives) that will attempt to lead revitalisation of te reo Māori on behalf of iwi and Māori. It is too early to determine what influence this group may have on Māori language revitalisation efforts. However, it is worth pointing out that not all Māori are convinced that this is the right approach to further Māori language initiatives (see comments by former Māori Language Commissioner Tīmoti Kāretu in “Te Karere TVNZ”, 2014).

It is important to note that much of the discussion and discourse (including publications mentioned in this article) around initiatives such as Te Mātāwai happen in Māori, sometimes with translations of varying quality being available in English. Much of the international commentary on Māori language revitalisation efforts, particularly around Māori language policy, is written by scholars who do not know Māori and therefore are limited to English language publications.

\section{Conclusion}

This paper has provided an overview of literature on Māori dialects and has noted some aspects of how Māori has changed-in terms of pronunciation, lexicality and grammar-in the revitalisation era. It has also described a recent increase in the use or promotion of Māori dialects, especially by younger speakers of Māori, most of whom have grown up and learnt Māori outside of their traditional tribal areas. I have argued that much of the discourse on dialects can be regarded as a language ideology, which is clearly a reflection of a speaker's language attitudes. Clearly there is a paucity of research on Māori attitudes towards Māori language and the changes currently happening, which are notoriously difficult to determine accurately.

The paper, due to lack of space, has made no attempt to provide a theoretical basis for the phenomenon of dialect ideologies, nor has it attempted to engage in any depth with the wider Māori language policy literature (see Albury, 2014), much of which is not cognisant of recent important developments such as $\mathrm{Te}$ Mātāwai and associated Māori language commentaries. Discourse written in Māori on social media (especially platforms such as Facebook, Twitter, Instagram and YouTube) remains an untapped source of rich complementary data, together with Māori language publications, on language attitudes and ideologies. There is still scope for further research on existing dialects because in some areas older speakers remain who have spent the majority of their lives in a particular dialect/iwi region. 


\section{Glossary}

āhei

e... ana

hunga/huna

iwi

kāore

kapahaka

karakia

kaumātua/kuia

kei te ...

kōhanga reo

kōrua/kourua

kura kaupapa

Māori

Mātaatua

mō

Ngāi Tahu/Kai

Tahu

Ngāti Kahungunu tribe based on the lower

Ngāti Porou
East Coast of the North

Island

to be able, possible, within

one's power

particle combination used

to indicate continuing

action or state

people

tribe

no

a group form of Māori

performing arts

incantation, prayer, chant

elders

particle used to indicate

continuing action

Māori-medium education

centre focusing on early

childhood and whānau

second person dual pronoun

Māori-medium education

for compulsory school

sector based on Māori

principles and practices

migration canoe, region

in the Central North

Island

first person plural exclusive pronoun

rhythm, intonation, pronunciation and sound of a language, accent, dialect, register particle indicating "for", "about", "concerning"

tribe based in the South

Island

tribe based on the East

Coast of the North

Island diction, elocution,
Ngāti Porou ki

Tāmaki

Ngāti Raukawa

Ngāti Toa

ngeru

nō

pakeke

parareka

poti

pouaru/poueru

pounamu/

pounemu

rātou

rīwai

rohe

taea

taewa

tāmoko

Taranaki

tātou

taura here

Te Arawa

Te Ati Awa

Te Paipera

te reo ake o Ngāti

Porou

te reo Māori

te reo Nāti

tori

Waikato-Tainui
Ngāti Porou domiciled in

Auckland

tribe based in the

Maungatautari-Tokoroa

area and parts of the

lower North Island

tribe based in the Kāwhia

region and parts of the

lower North Island

cat

no (Northland)

elder

potato (Ngāti Porou)

cat (Northland)

widow

greenstone

second person plural

pronoun

potato

district

to be able, accomplished, possible

potato (Taranaki)

traditionally based Māori

tattoos

mountain, district, tribal group

first person plural inclusive pronoun

affiliated groups

migration canoe, district, tribal grouping in Central North Island

tribe based in the Taranaki and Wellington regions

the Māori Bible

authentic Ngāti Porou

Māori

the Māori language

Māori as spoken in the

Ngāti Porou region

cat

tribal grouping covering the Waikato region 


$\begin{array}{ll}\text { wānanga } & \begin{array}{c}\text { university, insitution of } \\ \text { higher learning } \\ \text { causative prefix }\end{array} \\ \text { whaka-/haka- } & \begin{array}{l}\text { extended family; in } \\ \text { whānau }\end{array} \\ & \text { modern Māori (and New } \\ & \text { Zealand English) any } \\ & \text { group with a similar aim, } \\ & \text { purpose or goal }\end{array}$

\section{References}

Albury, N. J. (2014). Your language or ours? Inclusion and exclusion of non-indigenous majorities in Māori and Sámi language revitalization policy. Current Issues in Language Planning, 16(3), 315-334. http://doi.org/cdgg

Albury, N. J. (2016). An old problem with new directions: Māori language revitalisation and the policy ideas of youth. Current Issues in Language Planning, 17(2), 161-178. http://doi.org/cdgh

Bauer, W. A. (1981). Aspects of the grammar of Maori (Unpublished $\mathrm{PhD}$ thesis). University of Edinburgh, Scotland.

Bauer, W. A. (1993). Maori. London, UK: Routledge. http://doi.org/fdvgp8

Bauer, W. A. (1997). The Reed reference grammar of Māori. Auckland, New Zealand: Reed.

Benton, R. A. (1991). The Māori language: Dying or reviving? Honolulu, HI: East West Center.

Bible Society New Zealand. (2012). Te Paipera Tapu: The Holy Bible in Māori. Wellington, New Zealand: Author.

Biggs, B. (1952). The translation and publishing of Maori material in the Auckland Public Library. Journal of the Polynesian Society, 61, 177-191.

Biggs, B. (1961). The structure of New Zealand Maori. Anthropological Linguistics, 3(3), 1-54.

Biggs, B. (1966). English-Maori dictionary. Auckland, New Zealand: Reed.

Biggs, B. (1969). Let's learn Maori: A guide to the study of the Mãori language. Wellington, New Zealand: A. H. \& A. W. Reed.

Biggs, B. (1981). Complete English-Māori dictionary. Auckland, New Zealand: Auckland University Press.

Biggs, B. (1989). Towards a study of Māori dialects. In R. Harlow \& R. Hooper (Eds.), VICAL 1 Oceanic Languages: Papers from the Fifth International Conference on Austronesian Linguistics. Auckland, New Zealand: Linguistic Society of New Zealand.

Christensen, I. (2004). Te reo pāngarau: A Māori language dictionary of mathematics. Wellington, New Zealand: Ministry of Education.

Christensen, I. (2010). Te reo pūtaiao: A Māori language dictionary of science. Wellington, New Zealand: Ministry of Education.

De Bres, J. (2011). A review of research on the attitudes of non-Maori New Zealanders towards the Maori language in New Zealand. Studies in Applied Linguistics, 17(2), 5-19. 
Everitt, J. (1996). He Marautanga Reo mo Te Tai Tokerau. Whangarei, New Zealand: Publisher Unknown.

Harlow, R. (2001). A Māori reference grammar. Auckland, New Zealand: Longman.

Harlow, R. (2005). Covert attitudes to Maori. International Journal of the Sociology of Language, 172, 133-147. http://doi.org/fqg4xs

Harlow, R. (2007). Māori: A linguistic introduction. Cambridge, UK: Cambridge University Press. http://doi.org/c9td49

Harlow, R. (2015). A Māori reference grammar. Wellington, New Zealand: Huia.

Harlow, R., Keegan, P. J., King, J., Maclagan, M., \& Watson, C. (2009). The changing sound of the Māori language. In J. N. Stanford \& D. R. Preston (Eds.), Variation in indigenous minority languages (pp. 129-152). Amsterdam, The Netherlands: Benjamins. http://doi.org/cdgj

Higgins, R., Rewi, P., \& Olsen-Reeder, V. (Eds.). (2014). The value of the Māori language: Te hua o te reo Māori. Wellington, New Zealand: Huia.

Hohepa, P. W. (1967). A profile generative grammar of Māori. Indiana University Publications in Anthropology and Linguistics, Memoir 20. International Journal of American Linguistics. Baltimore, MD: Waverly Press.

Keegan, P. J. (2005). Maori vocabulary. In A. Bell, R. Harlow, \& D. Starks (Eds.), Languages of New Zealand (pp. 131-148). Wellington, New Zealand: Victoria University Press.

Keegan, P. J. (2017, January 4). Understanding Māori language statistics from New Zealand Census data. Retrieved from http://peterjkeegan.github. io/mstats01.html

Kelly, K. G. (2014). Iti te kupu, nui te kōrero: The study of the little details that make the Māori language Māori. In R. Higgins, P. Rewi, \& V. Olsen-Reeder (Eds.), The value of the Māori language: Te hua o te reo Māori (pp. 255-268). Wellington, New Zealand: Huia.

Kelly, K. G. (2015). Aspects of change in the syntax of Māori: A corpus-based study (Unpublished doctoral thesis). Victoria University of Wellington, New Zealand.

King, J. (2014). Revitalising the Māori language? In P. Austin \& J. Sallabank (Eds.), Endangered languages: Beliefs and ideologies in language documentation and revitalisation (pp. 215-230). Oxford, UK: Oxford University Press/British Academy. http://doi.org/cdgk

King, J., Watson, C., Maclagan, M., Harlow, R., \& Keegan, P. (2010). Maori women's role in sound change. In J. Holmes \& M. Marra (Eds.), Femininity, feminism and gendered discourse (pp. 191-211). Newcastle upon Tyne, UK: Cambridge Scholars Publishing.

Maclagan, M., \& King, J. (2002). The pronunciation of $w h$ in Māori: A case study from the late nineteenth century. Te Reo, Journal of the Linguistic Society of New Zealand, 45, 45-63.

MacLeod, J. T. (2014). He hua rānei tō te reo Māori mō ngā rā kei te heke mai? In R. Higgins, P. Rewi, $\&$ V. Olsen-Reeder (Eds.), The value of the Māori language: Te hua o te reo Māori (pp. 141-150). Wellington, New Zealand: Huia.

Makihara, M., \& Schieffelin, B. B. (2007). Consequences of contact: Language ideologies and sociocultural transformations in Pacific societies. New York, NY: Oxford University Press. http://doi.org/dtpmxb

Māori Language Commission-Te Taura Whiri i te Reo Māori. (1992). Te matatiki: Ngā kupu bou a Te Taura Whiri i te Reo Māori. Wellington, New Zealand: Author.

Māori Language Commission-Te Taura Whiri i te Reo Māori. (1996). Te matatiki: Contemporary Māori words. Auckland, New Zealand: Oxford University Press.

Ministry of Education. (1995). Te papakupupāngarau. Wellington, New Zealand: Learning Media.

Ministry of Education. (2012). Te Marautanga o Aotearoa. Wellington, New Zealand: Learning Media.

Mita. (n.d.). Māori Dictionary Online. Retrieved from http://maoridictionary.co.nz/search?idiom $=\& p h$ rase $=\&$ prover $b=\&$ loan $=\&$ histLoanWords $=\&$ ke ywords=mita

Ngāpuhi dialect speakers wanted for dictionary project. (2010, June). Te Waka Reo. Retrieved from https://cacenz.wordpress.com/2010/06/17/ te-waka-reo-june-2010-hrc/

Pihama, L., \& Matamua, R. (2017). Te Matatana o Te Reo: A national research agenda for the regeneration and revitalisation of Te Reo Māori. Report to He Puna Whakaranora, Te Taura Whiri i Te Reo Māori. Hamilton, New Zealand: Te Kotahi Research Institute/University of Waikato.

Reedy, T. M. (1979). Complex sentence formation in Maori (Unpublished $\mathrm{PhD}$ thesis), University of Hawai'i, United States.

Schieffelin, B. B., Woolard, K. A., \& Kroskrity, P. A. (Eds.). (1998). Language ideologies: Practice and theory. New York, NY: Oxford University Press.

Te Karere TVNZ. (2014, February 11). Timoti Karetu: Why return the language to those who 
let it die? [Video file]. Retrieved from https:// www.youtube.com/watch?v=GQ8Q9mS04M\&index=356\&list=LLS8w-1Fu1zwccwDJY glxzvA

Te Puni Kōkiri. (2009). 2009 Survey of attitudes, values and beliefs towards the Māori language. Wellington, New Zealand: Author.

Te Taura Here o Ngāti Porou ki Tāmaki. (2009). Nāti ki te Whare: Reo Māori Strategy and Action Plan 2010-2015. Retrieved from http://www.ngatiporouauckland.co.nz/ TTONPKT\%20Reo\%20Nati\%20Plan \% 20 Sept \%2009\%20v1_5.pdf

Te Taura Whiri i te Reo Māori. (2008). He pātaka kupu: Te kai a te rangatira. Auckland, New Zealand: Raupo.

Te Taura Whiri i te reo Māori. (2012). Guidelines for Māori orthography. Retrieved from http://www. tetaurawhiri.govt.nz/english/pub_e/downloads/ Nga\%20Tikanga\%20Tuhi-english.pdf

Waitangi Tribunal. (1986). Report of the Waitangi
Tribunal on the Te reo Māori claim: Wai 11. Wellington, New Zealand: Government Printer. Waitangi Tribunal. (2011). Wai 262: Ko Aotearoa tènei. A report into claims concerning New Zealand law and policy affecting Māori culture and identity. Wellington, New Zealand: Author.

Waititi, H. R. (1970). Te rangatahi: Elementary 1. Wellington, New Zealand: Government Printer.

Waititi, H. R. (1972). Te rangatahi: Elementary 2. Wellington, New Zealand: Government Printer.

Waititi, H. R. (1978). Te rangatahi: Elementary 3. Wellington, New Zealand: Government Printer.

Watson, C. I., Maclagan, M. A., King, J., Harlow, R., \& Keegan, P. J. (2016). Sound change in Māori and the influence of New Zealand English. Journal of the International Phonetic Association, 46(2), 185-218. http://doi.org/cdgm

Winiata, P. (2010). Whakatupuranga Rua ManoGeneration 2000: A case study. Retrieved from http://www.firstfound.org/Vol.\%207New_ Folder/winiata.htm 